\title{
Estimation of crown radii and crown projection area from stem size and tree position
}

\author{
Rüdiger GROTE* \\ Chair for Forest Yield Science, Department of Ecology and Landscape Management, TU Munich, Am Hochanger 13, 85354 Freising, Germany
}

(Received 4 July 2001; accepted 17 October 2002)

\begin{abstract}
This paper describes a method for crown radii estimation in different cardinal directions using tree diameter, height, crown length, and stem position within the stand as independent variables. The approach can serve for the initialisation of crown dimensions if measured crown radii are not available in order to address various research questions. Test calculations are carried out with 4 pure spruce (Picea abies L. Karst), 5 beech (Fagus sylvatica L.), and 6 mixed stands with both species. Simulated tree radii, crown projection area and canopy cover are compared with measurements and simple estimation procedures based on logarithmic and linear equations. In beech stands and dense spruce stands the estimates with the new approach are similar or superior to those obtained with the other methods. However, in sparse plots or in stands, which have experienced a recent thinning crown size of trees is overestimated.
\end{abstract}

crown projection area / crown radii / Fagus sylvatica / mixed forests / Picea abies

Résumé - Estimation des rayons et de la zone de projection de la couronne en utilisant les dimensions de la tige et la position de l'arbre. Cet article introduit une méthode mathématique qui permet une estimation du rayon, en utilisant seulement les dimensions de la tige de la couronne et la position de l'arbre. Cette méthode permet d'initialiser les dimensions de la couronne dans le cas où on ne connaît pas les rayons pour ainsi traiter de différentes questions scientifiques. La méthode est testée sur de nombreux peuplements d'épicéas (Picea abies) et de hêtres (Fagus sylvatica), non seulement constitués d'une seule essence mais aussi de forêts mixtes, dans le sud de l'Allemagne. Les simulations du rayon des couronnes, de la surface de projection d'une couronne et du degré de couverture sont comparées avec des mesures et d'autres estimations basées sur des équations linéaires ou logarithmiques. Les résultats montrent que la nouvelle méthode est appropriée pour la représentation des rayons des couronnes de hêtres et pour des peuplements denses d'épicéa. En revanche le rayon et la surface de la couronne d'arbres ayant poussé dans des lieux clairsemés ou ayant subi une éclaircie sont surestimés.

projection des couronnes / rayons des couronnes / Fagus sylvatica / forêts mixtes / Picea abies

\section{INTRODUCTION}

Many ecological and economic problems in forestry today (e.g. continuous cover forestry, wood production and quality) are approached using crown dimensional measures. For example, individual tree competition indices are derived from crown area estimates $[6,38]$ because crown dimension is a result of past competition as well as an indicator of the current growth potential [27]. Thus, crown dimensional measures are also used in more sophisticated single-tree models - particularly when forest growth in uneven-aged or mixed species stands is addressed [40]. Furthermore, crown size and canopy cover determine the probability of successful natural regeneration by its influence on the pattern of shade, light, and rainfall on the ground [49]. In general, many approaches of modelling light distribution (e.g. [48]), water balance (e.g. [2, 37]), tree growth (e.g. [7, 41]), and tree physiology (e.g. [50]) depend on information about crown dimensions of individual trees. Possibly, considering a more realistic crown shape will become increasingly important also for stem quality simulation, because branch dimension is one of the most important determinants [30].

Despite its importance crown extension remains difficult to determine. It can only be measured by optical methods from below [44] or from above [1], which both are subjected to a likely underestimation of crown width due to a limited visibility of crowns. The crown projection area can be estimated from stem dimensions $[15,52]$, but has to be thoroughly parameterised for specific stand conditions [18], which in most cases involves again a large number of direct measurements. Finally, canopy cover can not be assumed to be the sum of tree crown projection areas, because overlapping is a common phenomenon particularly in dense, uneven-aged, and mixed stands.

The difficult measurements and the sensitivity of crown dimension on management makes it desirable to develop estimation procedures based on variables that are easier to measure

\footnotetext{
* Corresponding author: ruediger.grote@imk.fzk.de
} 
Table I. Site description of the stands used for evaluation.

\begin{tabular}{|c|c|c|c|c|c|c|c|c|c|c|c|c|c|c|}
\hline \multirow[t]{2}{*}{ Location } & \multirow[t]{2}{*}{$\begin{array}{c}\text { Plot } \\
\text { no. }\end{array}$} & \multirow[t]{2}{*}{$\begin{array}{c}\text { Reference } \\
\text { year }\end{array}$} & \multirow[t]{2}{*}{$\begin{array}{c}\text { Year of last } \\
\text { thinning }\end{array}$} & \multicolumn{2}{|c|}{ Age } & \multirow[t]{2}{*}{$\begin{array}{c}\text { Plot size } \\
\left(\mathrm{m}^{2}\right)\end{array}$} & \multicolumn{2}{|c|}{$\begin{array}{l}\text { Average height } \\
\text { (m) }\end{array}$} & \multicolumn{2}{|c|}{$\begin{array}{l}\text { Average diameter } \\
(\mathrm{cm})\end{array}$} & \multicolumn{2}{|c|}{$\begin{array}{l}\text { Stand density } \\
\text { (trees/ha) }\end{array}$} & \multirow{2}{*}{$\begin{array}{c}\text { Basal } \\
\text { area } \\
\left(\mathrm{m}^{2} / \mathrm{ha}\right)\end{array}$} & \multirow{2}{*}{$\begin{array}{c}\text { Area } \\
\text { thinned* } \\
\left(\mathrm{m}^{2} / \mathrm{ha}\right)\end{array}$} \\
\hline & & & & Spruce & Beech & & Spruce & Beech & Spruce & Beech & Spruce & Beech & & \\
\hline \multirow[t]{4}{*}{ Eurach } & 1 & 1999 & 1996 & 47 & & 1178 & 13.89 & & 14.93 & & 1477 & & 25.9 & 0 \\
\hline & 2 & & & 47 & & 1087 & 9.85 & & 11.07 & & 1638 & & 15.8 & 2.9 \\
\hline & 3 & & & 47 & & 1140 & 13.51 & & 13.67 & & 1316 & & 19.3 & 6.5 \\
\hline & 4 & & & 47 & & 1197 & 13.79 & & 16.51 & & 902 & & 19.3 & 4.1 \\
\hline \multirow[t]{5}{*}{ Starnberg } & 1 & 1993 & 1986 & & 66 & 1520 & & 16.51 & & 17.58 & & 623 & 15.1 & 3.8 \\
\hline & 2 & & & & 66 & 1314 & & 20.64 & & 23.43 & & 731 & 31.5 & 0.1 \\
\hline & 3 & & & & 66 & 1423 & & 16.38 & & 16.75 & & 485 & 10.7 & 4.6 \\
\hline & 4 & & & & 66 & 1572 & & 18.24 & & 20.8 & & 560 & 19.0 & 3.8 \\
\hline & 5 & & & & 66 & 1623 & & 19.69 & & 19.68 & & 327 & 9.9 & 4 \\
\hline \multirow[t]{6}{*}{ Freising } & 1 & 1994 & unknown & 44 & 51 & 4285 & 23.51 & 22.28 & 24.66 & 19.28 & 558 & 352 & 36.9 & \\
\hline & 2 & & & 77 & 97 & 5301 & 38.9 & 30.74 & 32.74 & 44.66 & 562 & 63 & 57.2 & \\
\hline & 3 & & & 95 & 120 & 3071 & 43.83 & 47.94 & 37.14 & 50.87 & 168 & 130 & 44.6 & \\
\hline & 4 & & & 88 & 103 & 2470 & 40.64 & 42.89 & 35.62 & 28.84 & 415 & 149 & 51.1 & \\
\hline & 5 & & & 42 & 54 & 1983 & 26.64 & 17.83 & 14.98 & 17.25 & 1214 & 456 & 32.1 & \\
\hline & 6 & & & 37 & 54 & 2642 & 25.51 & 13.42 & 16.18 & 12.29 & 847 & 1032 & 29.7 & \\
\hline
\end{tabular}

* Expressed in basal area loss, only dominant trees considered.

than crown extension itself. Thus, maximum crown radius, which can be derived from stem diameter, has been used to estimate crown projection area [19, 51]. Because increasing stand density results in increasing overestimates an adjustment factor has been introduced that is generally derived from overlap estimates [13]. More recently, average crown radius and canopy cover in several types of conifer forests were successfully estimated with regression equations that have been derived from stem diameter, height, and/or crown length [17]. All of these methods are developed to give reliable results on the stand level, which is suitable for many of the purposes mentioned above. It is not sufficient, however, for analyses that account explicitly for the asymmetry of crowns. Information about asymmetric crown extension has been used e.g. for detailed ecosystem characterisation [47] or the simulation of wood quality [28, 45], radiation distribution [10, 11], susceptibility of trees to windthrow [46], crown biomass [22], and individual tree physiology [23]. Therefore, a method, which estimates crown radii in various cardinal directions for every tree in a given stand would be of great value for these research areas. In this paper, such an approach is presented that is based on the size of a tree and the size and position of surrounding competitors. Also, the sum of crown projection area and canopy cover (the total area covered by canopy) are both calculated based on the estimated radii and results are compared with those obtained with other methods.

\section{MATERIALS AND METHODS}

\subsection{Stand description}

In order to test the proposed method for crown radii estimation, a number of forest stands were selected that include the most important tree species and stand structure types in Germany. The stands consist of trees with a coniferous (Picea abies L. Karst.) and a broadleaved
(Fagus sylvatica L.) tree species either in pure or mixed stands. All of them belong to the network of long-term investigation plots in Bavaria, South Germany and are maintained by the Chair for Forest Yield Science in Freising. Thus, tree position, stem diameter, height, height of crown base, and crown radii length had already been measured at many trees. The plots of pure spruce (Eurach, 4 plots) and beech (Starnberg, 5 plots) both represent different degrees of stand density. The mixed plots (Freising, 6 plots) represent different age classes. All plots of one site are located closely together to minimise differences in site conditions. For a more detailed description see Table I. The plots of pure spruce and the mixed plots are furthermore described in connection with other investigations [20,42].

Diameter at breast height had been measured with a girth tape at all trees. Tree height and crown base height of each tree within one plot had been determined from height-diameter relations that are derived from a subset of approximately 40 measured heights at each plot. The visible crown extension in each of eight cardinal directions had been measured by vertically looking up as described by Röhle [43]. Calculations are carried out with all trees within the plots, but trees at the plot boundaries are omitted from the results. This is necessary because in these cases no competitors at the outward side are considered and crown radii would thus be overestimated.

\subsection{Distance dependent approach}

The suggested approach is based on two assumptions. The first is that the potential horizontal crown extension is a function of stem diameter, and the second is that the distance between the tree and its competitors determines the actual crown dimension within the limit of the potential crown extension. Following Arney [3], competitors are defined as trees with an overlap in potential crown extensions (Fig. 1A). Crown radius length in a particular direction is limited by the position of competitors within a certain angle on both sides of the radius (Figs. 1A and 1B) and by their crown width at the height where the maximum crown extension of a centre tree is assumed (Fig. 1C). The method is further on referred to as 'maximum radii estimation' (MRE). 
A)

B)

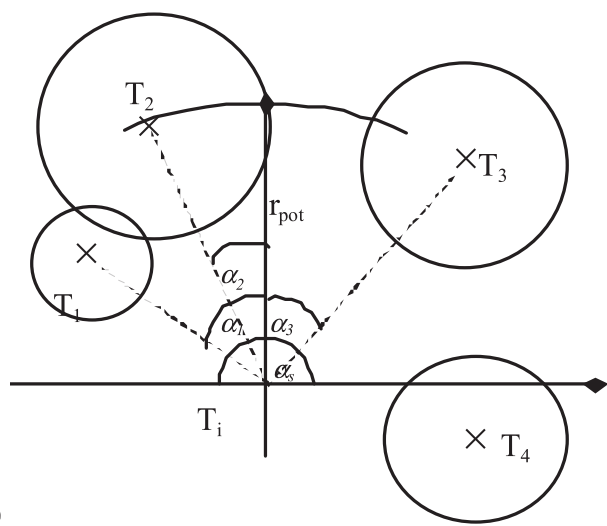

C)
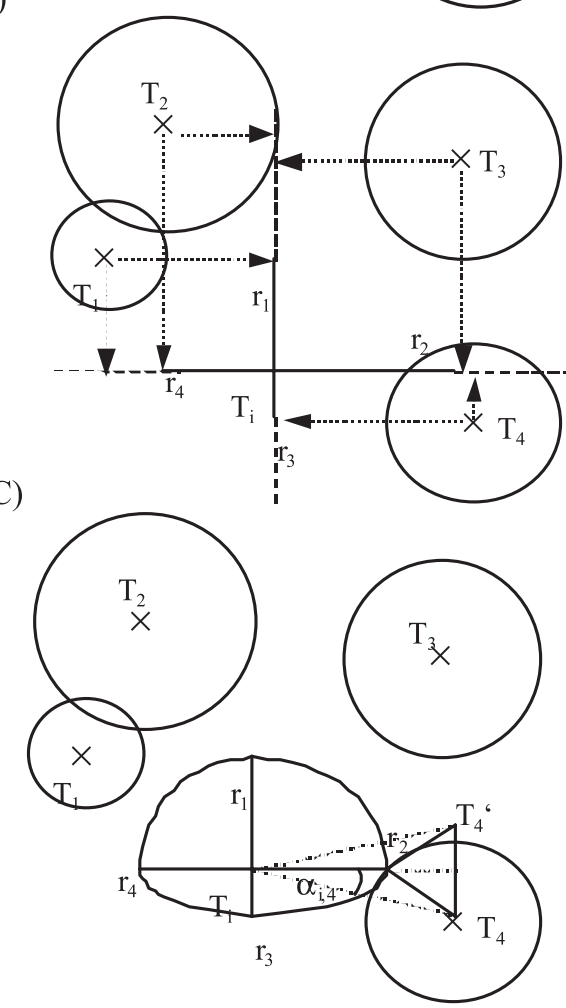

Figure 1. Determination of maximum crown radius per cardinal direction. (A) Selection of competitor trees that are in the range of the centre tree. (B) Radius limitation for $r_{1-4}$ by competitor positions (stem position of a competitor tree is indicated by a cross). (C) Radius limitation by competitor crown extension (here only for $r_{2}$ ). $\mathrm{T}_{\mathrm{i}}=$ centre tree, $r_{\text {pot }}=$ potential radius of $\mathrm{T}_{\mathrm{i}}, \mathrm{T}_{1-4}=$ competitors with crown width at the height of maximum crown extension of $\mathrm{T}_{\mathrm{i}}, \alpha_{\mathrm{s}}=$ angle between simulated radii (only 4 radii $\left(r_{1-4}\right)$ are considered, whereas the calculations are based on 8 radii), $\alpha_{1-3}=$ angle between $\mathrm{T}_{\mathrm{i}}$ and the competitors relevant for the determination of $r_{1}, \mathrm{~T}_{4}{ }^{\prime}=$ virtual mirror tree for determination of radius length $r_{2}$.

Firstly, in order to determine the height where maximum crown width occurs, a crown shape function is required similar to those that have been suggested by several authors during the last decades (e.g. $[8,25,26,29,35])$. However, these equations require many parameters that are not directly measurable (e.g. [25]), assume a steady increase with canopy depth (e.g. [35]), or end with a zero-radius at

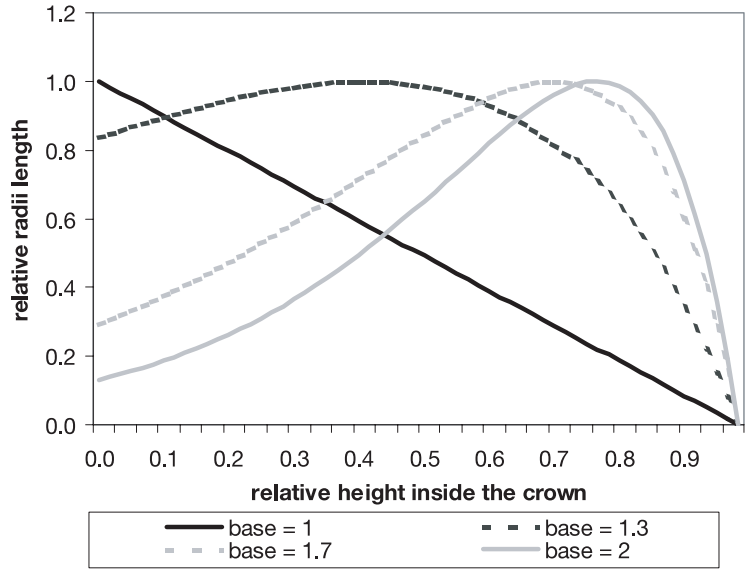

Figure 2. Effect of the 'base'-variable in equation 1 on crown shape (inserting a crown length of $15 \mathrm{~m}$ for $l_{c r}$ ). $0=$ crown base, $1=$ tip of the tree.

crown base height (e.g. [29]). In the current context, these properties are considered as disadvantages. Thus, a new one-parameter equation is used that describes crown radius at every height $h\left(r_{h}\right)$ as a function of crown base height ( $h c r)$, crown length (lcr), and the maximum radius in a particular cardinal direction $\left(r_{\text {max }}\right)$. The term $\mathrm{relH}$ refers to the relative height within the crown, which is 0 at crown base and 1 at the tip of the tree.

$$
\begin{gathered}
r_{h}=r_{\max } \cdot \frac{(1-r e l H) \cdot f(h)}{\max [(1-r e l H) \cdot f(h)]} \\
r e l H=\frac{h-h c r}{l c r} \\
f(h)=\text { base }
\end{gathered}
$$

The effect of the base-term in equation (1c) is demonstrated in Figure 2, with $r_{\max }=1$ and a crown length of $15 \mathrm{~m}$. In a detailed analysis of 12 trees, values of base were found to be $1.23 \pm 0.074$ for spruce and $2.02 \pm 0.71$ for beech [21]. However, the standard deviation can be decreased if base is derived from crown length according to equation (1d) $(1.23 \pm 0.071$ for spruce and $2.08 \pm 0.345$ for beech) with $p s$ equal to $0.018\left(\mathrm{R}^{2}=0.65\right)$ and $0.0756\left(\mathrm{R}^{2}=0.54\right)$ for spruce and beech respectively.

$$
\text { base }=1+p s \cdot l c r
$$

ps: shape parameter.

To determine the maximum crown radii of one tree, the maximum crown extension for the competitor trees $j$ are needed but generally not known. Thus, for a given competitor, $r_{\mathrm{max}, j}$ is calculated from the distance to tree $i\left(d_{i j}\right)$ and from diameter at breast height $(d b h)$ of both trees according to equation 2 . The distance between a tree and its competitor $d_{i j}$ can easily be calculated from stem positions.

$$
r_{\text {max }, j}=d_{i j} \cdot \frac{d b h_{j}}{d b h_{j}+d b h_{i}} .
$$

However, $r_{\max }$ of any tree is limited to its potential radius $\left(r_{p o t}\right)$, which describes the physical maximum is hardly affected by site conditions [24]. Since no open grown trees were available, $r_{p o t}$ is estimated from the $5 \%$ relative largest crown radii found at the trial plots. 

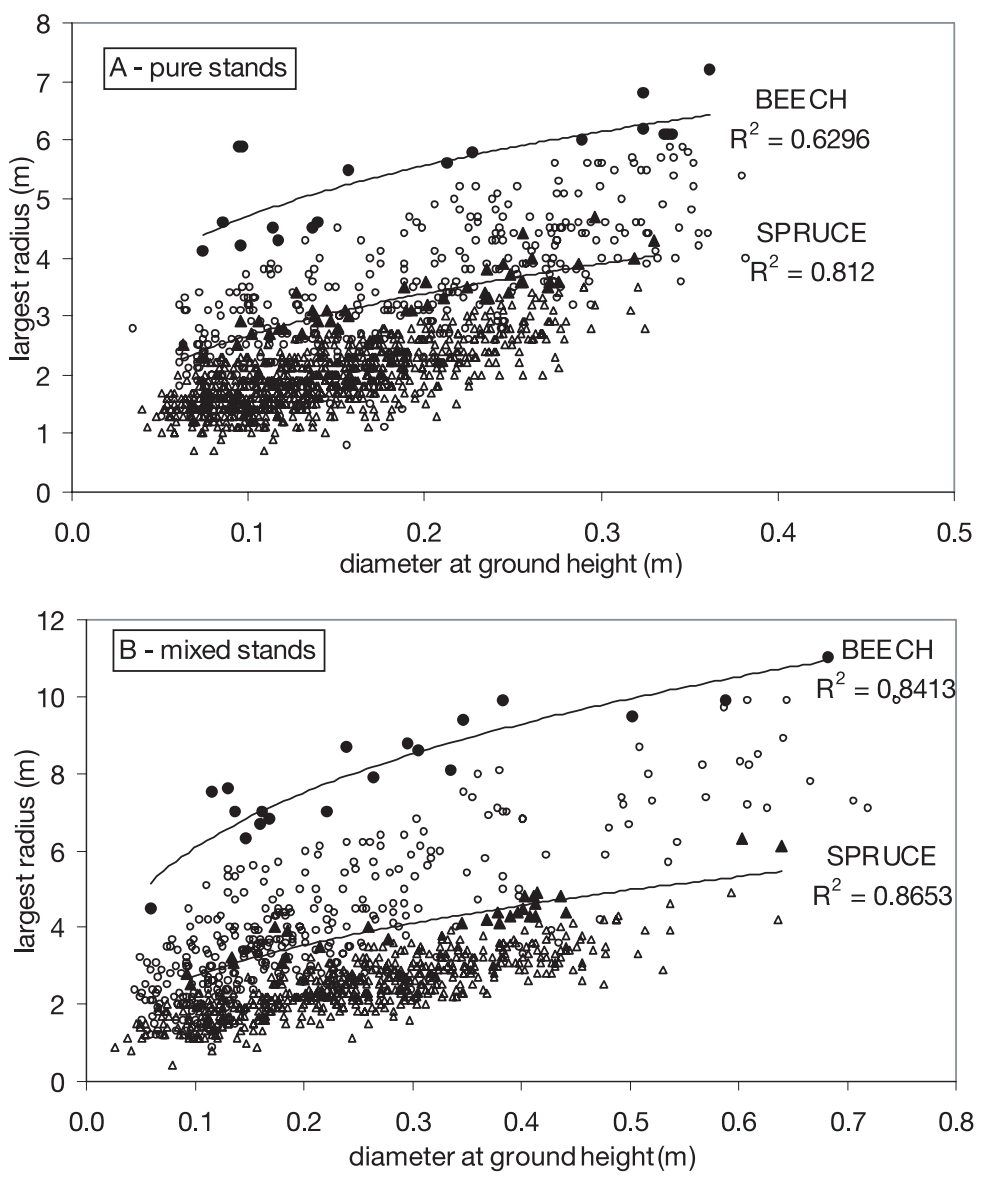

Figure 3. Measured crown radii in dependence on stem diameter at ground height. The lines indicate the potential radius $r_{\text {pot }}$ for a given diameter separated for tree species (beech: circles, spruce: triangles) and stand type (A: pure stands, B: mixed stands). Larger points and triangles indicate the $5 \%$ of relative largest radii that are used to build the boundary function.
To determine these radii, firstly all radii (with 8 radii measured per tree) are exponentially fitted to the stem diameter at ground height $d o$ (MS Excel software package). The 5\% selected radii are the ones with the largest positive deviation from this relation. Another exponential fit through these radii according to equation 3 derives the parameter $p r_{1}$ and $p r_{2}$. The diameter at ground height is derived from $d b h$ by assuming a certain diameter decrease of the bole with increasing height $\left(0.3 \mathrm{~cm} \mathrm{~m}^{-1}\right)$. It is used as independent variable instead of $d b h$ because otherwise equation 3 would imply that small trees $(<1.3 \mathrm{~m}$ height) have no crowns at all, which would restrict the generality of the approach. Parameters are determined separately for each tree species and for pure and mixed stands although the differences between the relations for spruces in different stand structure types were not significant (Fig. 3). Values for $p r_{1}$ and $p r_{2}$ together with the number of radii that have been used to derive the functions are given in Table II.

$$
r_{p o t}=p r_{1} \cdot d o r^{p r_{2}}
$$

( $r_{p o t}$ and $d o$ in $\left.\mathrm{m}\right)$.

From $r_{\max , j}$ the potential crown extension of all competitor trees is calculated for every height according to equation 1 in height steps of $0.5 \mathrm{~m}$. In this calculation, $r_{h}$ of competing trees below the height of maximum crown diameter is set to $r_{\max }$ to better account for the influence of light competition in deeper canopy layers.

In the next step, the angle $\alpha_{i j}$ between the tree ( $i$ ) and its competitor $(j)$ is calculated from tree positions (Fig. 1A). Assuming that a branch will grow until it reaches the crown circumference of a competitor tree, the length of each crown radius is calculated as follows (Fig. 1C):

$$
\begin{gathered}
r_{h, i}=\min \left(\overline{T_{i} S}, r_{p o t h, i}\right) \\
\overline{T_{i} S}=\cos \alpha_{i j} \cdot d_{i j}-l \\
l=r_{p o t h, j} \cdot \overline{T_{j} T_{j}^{\prime}}
\end{gathered}
$$

$r_{h, i}$ : actual radius of centre tree $i$ at height $h ; r_{\text {poth }, i}:$ potential radius of centre tree $i$ in height $h ; r_{\text {poth }, j}$ : potential radius of competitor tree $j$ in height $h ; T_{i} S$ : distance between stem position and the point of intersection; $l$ : help variable; $T_{j} T_{j}^{\prime}$ : distance between competitor tree $\mathrm{j}$ and a point, mirrored at the radius prolongation $\left(T^{\prime}{ }_{j}\right.$ is described as a 'virtual mirror tree' in Fig. 1C).

The actual radius of $r_{h, i}$ is calculated as the minimum radius determined by considering every competitor within angle $\alpha_{S}$ on both sides of the radius (see illustration in Fig. 1A). Based on former investigation results $[33,44]$ and test calculations with different angles, $\alpha_{\mathrm{s}}$ is set to $45^{\circ}$ ( 8 radii).

Since first calculations showed that the largest crown radii in one direction was too often equal to the potential radii, a further restriction was introduced to get more realistic results for $r_{\max }$. As illustrated in Figure $1 \mathrm{~B}$, the assumption is made that a radius can not grow beyond 
Table II. Parameter, estimated for determination of radius length and potential crown cover (pr1 and pr2: maximum radii, alin1 and blin1: linear radii estimation, alog and blog: logarithmic crown area estimation, alin1 and blin2: linear crown area estimation, see text for equations and dimensions).

\begin{tabular}{|c|c|c|c|c|c|c|c|c|}
\hline & \multicolumn{4}{|c|}{ Pure stands } & \multicolumn{4}{|c|}{ Mixed stands } \\
\hline & Spruce & $n$ & Beech & $n$ & Spruce & $n$ & Beech & $n$ \\
\hline pr1 & 5.89 & 46 & 8.24 & 19 & 6.43 & 29 & 12.30 & 19 \\
\hline pr2 & 0.34 & & 0.24 & & 0.37 & & 0.31 & \\
\hline alin1 & 5.24 & $\begin{array}{c}486 \\
4\end{array}$ & 7.28 & $\begin{array}{c}181 \\
9\end{array}$ & 7.09 & $\begin{array}{c}324 \\
4\end{array}$ & 8.51 & $\begin{array}{c}271 \\
2\end{array}$ \\
\hline blin 1 & 0.66 & & 0.86 & & 0.44 & & 0.73 & \\
\hline alog & -1.38 & 607 & -0.97 & 231 & -1.28 & 411 & -0.91 & 342 \\
\hline blog & 0.67 & & 0.70 & & 0.60 & & 0.68 & \\
\hline alin2 & -1.98 & 607 & -4.44 & 231 & 1.13 & 411 & -6.00 & 342 \\
\hline blin2 & 0.68 & & 1.33 & & 0.52 & & 1.43 & \\
\hline
\end{tabular}

the stem position of a competitor tree. Despite these limitations, it should be recognised that an overlap between crowns can result from the elliptical connection between two adjacent radii (see further down).

\subsection{Other calculations}

Currently, the most common estimation procedures of crown projection area are based on linear [17] or logarithmic [31, 52] relationships between stem and crown diameter. Thus, simple calculations are carried out using linear correlations between $d b h$ and radius length $\left(r_{\max }\right.$ in $\left.\mathrm{dm}=a_{\text {lin } 1}+b_{\text {lin } 1} \times d b h\right)$, and $d b h$ and crown projection area $\left(A\right.$ in $\mathrm{m}^{2}=a_{\text {lin } 2}+b_{\text {lin } 2} \times d b h$ in $\left.\mathrm{cm}\right)$ of individual trees. Crown projection area is also calculated with a logarithmic relation to stem cross-sectional area $\left(\ln A=a_{l o g}+b_{l o g} \times \ln \left(d b h^{2} \times \pi \times 0.25\right)\right)$. The parameter $a_{l o g}$ and $b_{l o g}$ are derived analytically from the same data set as $p r_{1}$ and $p r_{2}$ and are also presented in Table II for each tree species and for pure and mixed plots (not for each plot!). In order to derive crown projection area from measured and simulated crown radii, the area between the radii is considered as a fraction of an ellipse [44]. Canopy cover is calculated with a computer program that draws the crown projection area of every tree on a grid and counts the number of coloured pixels.

\section{RESULTS}

The relation between simulated and measured radii is shown in Figures 4A-4D. The coefficient of determination ranges from 0.2 for pure spruce to 0.45 for beech in mixed stands. A small bias is obvious in every figure, which indicates an overestimation of small radii and an underestimation of large radii. This is at least partly due to radii that had been measured with zero length, which can not be represented with the MRE method due to the assumption made in equation 2. Slope values with the regression line forced through the origin are presented in Table III separately for species and sites together with the respective $\mathrm{R}^{2}$ values. The table shows that despite the bias positive correlation coefficients had been
Table III. Comparison of the distance dependent method and the dbh-based estimation of crown radii (MRE: distance dependent method with 8 radii based estimation, LIN: based on linear correlation to $\mathrm{dbh} ; *=$ within $10 \%$ confidence interval, $* *=$ within $5 \%$ confidence interval).

\begin{tabular}{llllclc}
\hline Location & Species & $n_{\text {radii }}$ & $\begin{array}{c}\text { Slope } \\
(\mathrm{MRE})\end{array}$ & $\begin{array}{c}r^{2} \\
(\mathrm{MRE})\end{array}$ & $\begin{array}{c}\text { Slope } \\
(\mathrm{LIN})\end{array}$ & $\begin{array}{c}r^{2} \\
(\mathrm{LIN})\end{array}$ \\
\hline Eurach & spruce & 4864 & $0.957^{* *}$ & 0.08 & $0.912^{*}$ & -0.27 \\
Starnberg & beech & 1384 & $0.825^{*}$ & 0.27 & $0.878^{* *}$ & -0.34 \\
Freising & spruce & 1816 & $1.111^{*}$ & 0.26 & $0.907^{*}$ & -0.41 \\
Freising & beech & 1808 & 0.762 & 0.42 & 0.809 & -0.38 \\
Freising & mixed & 3624 & $0.898^{*}$ & 0.26 & 0.847 & -0.28 \\
\hline
\end{tabular}

obtained with the MRE method in all cases, but not with the estimation based on the linear approach.

Figure 5 and Table IV show that MRE does not decrease the accuracy of crown projection area estimates compared with the fitted logarithmic (LOG) and the linear method (LIN). The slope values obtained with every method are similar (in average over all plots separated by species: $\mathrm{MRE}=1.00, \mathrm{LOG}=$ 0.91 , LIN $=0.96$ ) although the standard deviation of MRE is highest $(\mathrm{MRE}=0.25, \mathrm{LOG}=0.12, \mathrm{LIN}=0.15)$. The $\mathrm{R}^{2}$ values of MRE are similar to those obtained with the LOG approach and are higher than $\mathrm{R}^{2}$ values obtained with the linear approach $(\mathrm{MRE}=0.64 \pm 0.15, \mathrm{LOG}=0.61 \pm 0.16, \mathrm{LIN}=$ $0.50 \pm 0.23$, with all negative values excluded from the average). However, crown projection area for spruce is somewhat overestimated, particularly in the mixed plots $(+4$ and $+28 \%$ mean deviation from measurements for pure and mixed plots respectively), whereas for beech it is generally underestimated $(-15$ and $-17 \%)$.

The goodness of fit apparently depends on the density of the plot and of the thinning intensity that the stand has been treated with (see Tab. I). In the plots Eurach 1 and Starnberg 2, which are the most dense for each species, the deviation from the 1:1 line is only marginal (spruce $-4 \%$, beech $+1 \%$ ) and the simulated values are closely correlated with measured crown projection area $\left(\mathrm{R}^{2}=0.7\right.$ and 0.8 for spruce and beech respectively). In spruce, overestimation increases in sparser plots (up to $23 \%$ in the sparsest plot Eurach 2), whereas for beech crown projection area is underestimated in thinned plots but no particular trend with the intensity of thinning is obvious.

The sum of crown projection areas within one plot is similar to that calculated from the measurements although an overestimation for spruce $(+9 \%)$ and an underestimation for beech $(-19 \%)$ is obtained (Tab. V). Again, the simulation of the densest plots for both species are closest to the measurements (Eurach 1: $-6 \%$, Starnberg 2: $-4 \%$ ).

Table V shows canopy cover values derived from either measured or simulated crown radii. Additionally, crown overlap is calculated from the difference between the sum of single tree crown projection areas and canopy cover. This demonstrates that the overlap derived with the MRE method is generally too small. In spruce stands, however, this underestimation is only slight $(-3 \%)$, whereas it is in average $-14 \%$ for beech stands. Mixed stands are in between (in average $-6 \%$ ). 

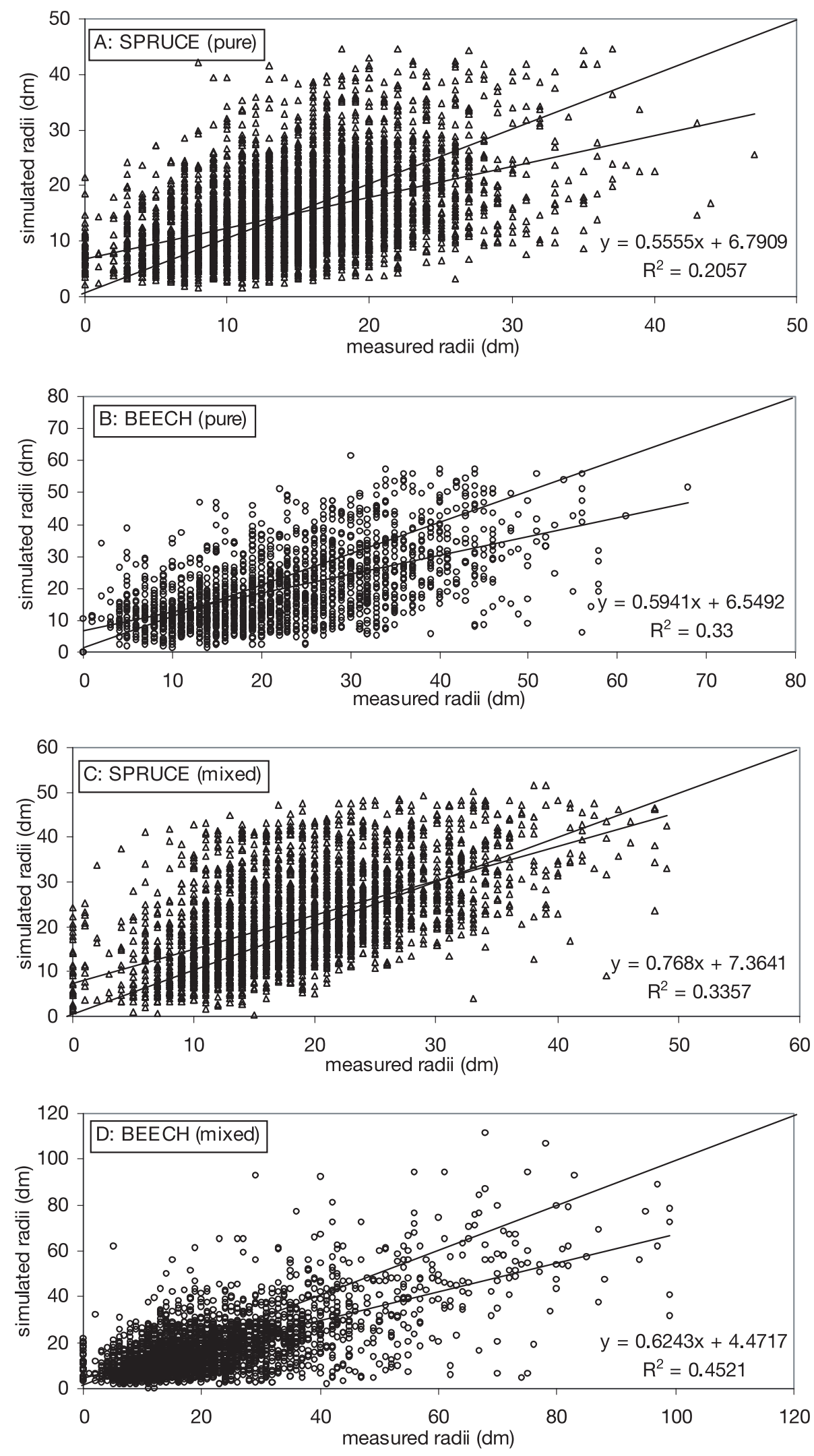

Figure 4. Simulated vs. measured crown radii in pure stands (A: spruce, B: beech) and mixed stands (C: spruce, D: beech). 

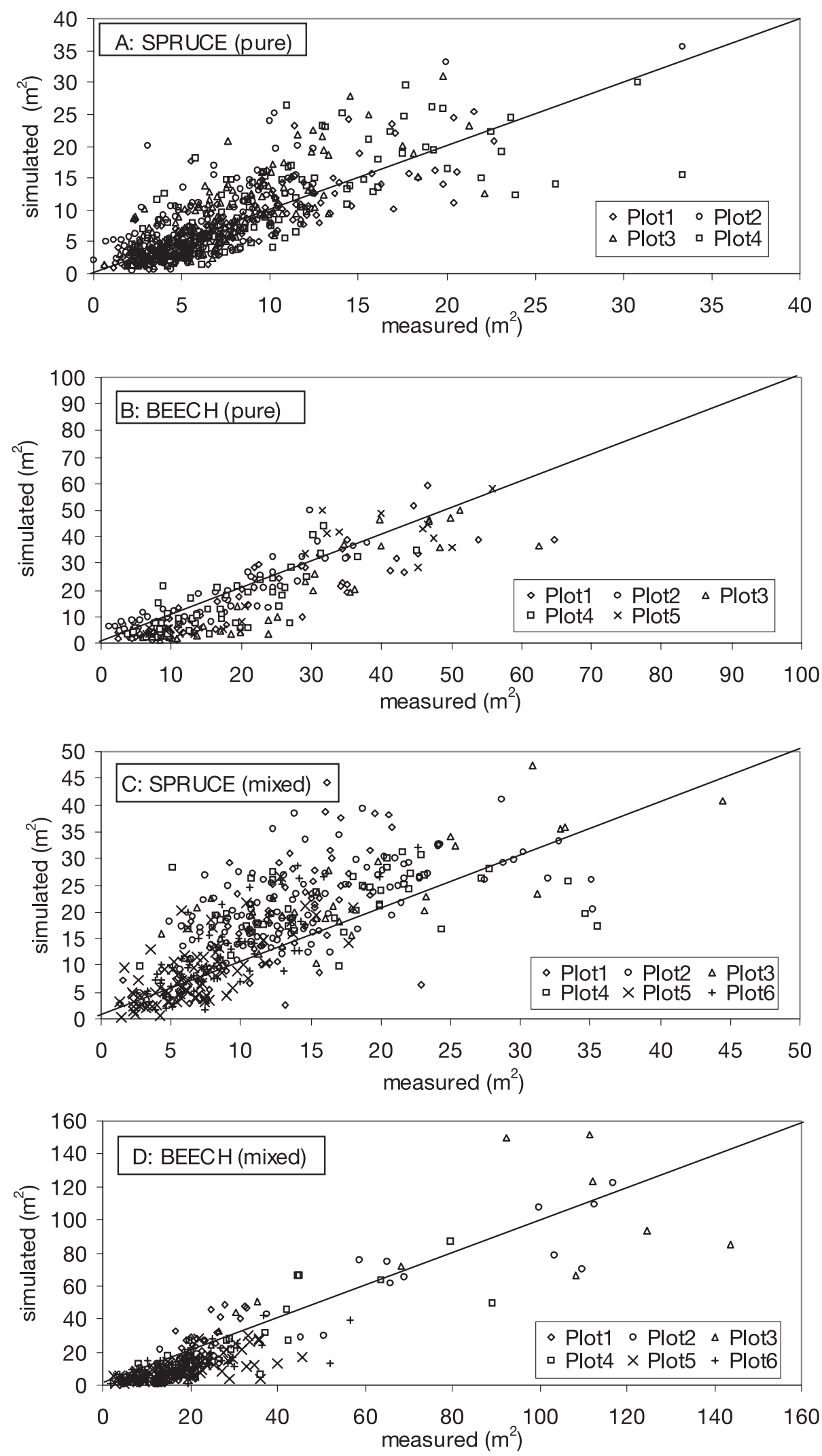

Figure 5. Comparison of crown projection areas calculated from simulated and measured crown radii in pure stands (A: spruce, B: beech) and mixed stands (C: spruce, D: beech). 
Table IV. Slope and correlation coefficients of simulated against measurement-based crown cover calculations ( $n$ : number of trees that are considered for the calculations, MRE: distance dependent method, LOG: based on logarithmic correlation, LIN: based on linear correlation).

\begin{tabular}{|c|c|c|c|c|c|c|c|c|c|}
\hline Location & Plot no. & Species & $n$ & Slope (MRE) & $r^{2}$ (MRE) & Slope (LOG) & $r^{2}$ (LOG) & Slope (LIN) & $r^{2}(\mathrm{LIN})$ \\
\hline \multirow[t]{5}{*}{ Eurach } & 1 & Spruce & 174 & 0.96 & 0.70 & 0.99 & 0.73 & 0.97 & 0.69 \\
\hline & 2 & & 172 & 1.23 & 0.63 & 0.91 & 0.53 & 0.91 & 0.50 \\
\hline & 3 & & 154 & 1.17 & 0.62 & 0.94 & 0.53 & 0.94 & 0.48 \\
\hline & 4 & & 108 & 1.00 & 0.48 & 0.81 & 0.54 & 0.79 & 0.44 \\
\hline & \multicolumn{2}{|c|}{ Over all } & 608 & 1.04 & 0.56 & 0.91 & 0.63 & 0.90 & 0.58 \\
\hline \multirow[t]{6}{*}{ Starnberg } & 1 & Beech & 60 & 0.80 & 0.78 & 0.87 & 0.85 & 0.86 & 0.82 \\
\hline & 2 & & 60 & 1.01 & 0.80 & 1.24 & 0.54 & 1.24 & 0.28 \\
\hline & 3 & & 38 & 0.76 & 0.79 & 0.77 & 0.85 & 0.75 & 0.86 \\
\hline & 4 & & 48 & 0.85 & 0.63 & 0.95 & 0.52 & 0.97 & 0.46 \\
\hline & 5 & & 27 & 0.92 & 0.81 & 0.85 & 0.86 & 0.83 & 0.87 \\
\hline & \multicolumn{2}{|c|}{ Over all } & 173 & 0.85 & 0.76 & 0.91 & 0.68 & 0.90 & 0.61 \\
\hline \multirow[t]{7}{*}{ Freising } & 1 & Spruce & 65 & 1.50 & 0.43 & 0.86 & 0.50 & 1.03 & 0.38 \\
\hline & 2 & & 119 & 1.31 & -0.15 & 0.98 & -0.24 & 1.10 & -1.30 \\
\hline & 3 & & 31 & 1.17 & 0.37 & 0.84 & -0.61 & 0.93 & -1.88 \\
\hline & 4 & & 44 & 1.10 & -1.25 & 0.97 & 0.37 & 1.05 & -0.05 \\
\hline & 5 & & 83 & 1.20 & 0.48 & 0.90 & 0.49 & 1.21 & 0.11 \\
\hline & 6 & & 69 & 1.41 & 0.67 & 0.79 & 0.69 & 1.05 & 0.31 \\
\hline & \multicolumn{2}{|c|}{ Over all } & 227 & 1.28 & 0.46 & 0.92 & 0.60 & 1.06 & 0.37 \\
\hline \multirow[t]{7}{*}{ Freising } & 1 & Beech & 98 & 0.73 & 0.37 & 1.10 & 0.55 & 1.20 & 0.57 \\
\hline & 2 & & 18 & 0.93 & 0.87 & 0.98 & 0.77 & 0.89 & 0.53 \\
\hline & 3 & & 11 & 0.95 & 0.43 & 0.79 & -0.53 & 0.72 & -1.56 \\
\hline & 4 & & 24 & 0.88 & 0.64 & 0.96 & 0.33 & 0.96 & 0.15 \\
\hline & 5 & & 73 & 0.55 & 0.49 & 0.85 & 0.43 & 0.95 & 0.40 \\
\hline & 6 & & 118 & 0.61 & 0.69 & 0.68 & 0.68 & 0.75 & 0.68 \\
\hline & \multicolumn{2}{|c|}{ Over all } & 226 & 0.83 & 0.77 & 0.89 & 0.77 & 0.88 & 0.69 \\
\hline \multirow[t]{7}{*}{ Freising } & 1 & Total & 162 & 0.92 & 0.19 & 1.04 & 0.59 & 1.16 & 0.61 \\
\hline & 2 & & 137 & 1.03 & 0.71 & 0.98 & 0.88 & 0.95 & 0.75 \\
\hline & 3 & & 42 & 0.98 & 0.73 & 0.80 & 0.75 & 0.75 & 0.63 \\
\hline & 4 & & 68 & 0.95 & 0.44 & 0.96 & 0.56 & 0.99 & 0.43 \\
\hline & 5 & & 156 & 0.64 & 0.22 & 0.86 & 0.69 & 0.98 & 0.56 \\
\hline & 6 & & 187 & 0.73 & 0.39 & 0.70 & 0.71 & 0.80 & 0.60 \\
\hline & \multicolumn{2}{|c|}{ Over all } & 453 & 0.93 & 0.66 & 0.90 & 0.77 & 0.91 & 0.66 \\
\hline
\end{tabular}

\section{DISCUSSION}

Results indicate that the MRE method can be used to estimate crown radii for beech and spruce in dense stands but has to be applied cautiously. Although some of the variance may be due to the high inaccuracy of crown measurements [43], crown radii of trees from sparse plots or in recently thinned stands are generally overestimated. This is consistent with the underlying assumption of a balanced crown extension, which can not be expected in heavily thinned stands and which is more likely with morphological flexible tree species like beech than with spruce $[4,16]$.

Future tests and improvements of the MRE approach will focus on crown shape estimation, which is based on a quite small sample size of trees yet. Only a larger sample provides the possibility to establish dependencies of crown shape on spacing and competition that have been already found in other investigations [5, 12, 14, 32, 34]. Further improvements could be based on the finding that in mixed stands spruce radii are generally over and beech radii are underestimated. This would be mitigated if a species-specific weighing factor for the calculation of potential spruce and beech radii is introduced in equation 2. However, it is not clear from the limited set of test sites to which degree the effect is due to the stand structure rather than species-specific properties. Although they are older, most beeches of the mixed plots are smaller than the spruces. Thus, the assumption that crowns of small trees are restricted by the largest extension of competitor crowns rather than their actual extension may affect beeches more than the spruces at these particular plots. In this case, separate crown radii estimations for different crown layers may produce more favourable results but simulations of differently structured mixed stands are required to test this assumption.

Improvements in crown radii estimates will generally positively affect crown projection area and canopy cover estimates. Nevertheless, the good agreement of simulated and measured canopy cover despite the underestimation of crown projection area in beech stands shows that the estimation of 
Table V. Comparison of total crown area and covered ground area, calculated from measured and estimated crown radii (MRE: distance dependent method, sd: standard deviation).

\begin{tabular}{|c|c|c|c|c|c|c|c|c|c|c|c|c|c|c|c|c|}
\hline \multirow[t]{2}{*}{ Location } & \multirow[t]{2}{*}{ Plot no. } & \multirow[t]{2}{*}{ Species } & \multicolumn{5}{|c|}{ Sum of crown area } & \multicolumn{5}{|c|}{ Sum of crown covered ground } & \multicolumn{4}{|c|}{ Multiple coverage } \\
\hline & & & $\begin{array}{c}\text { Measured } \\
\left(\mathrm{m}^{2}\right)\end{array}$ & sd & $\begin{array}{l}\text { MRE } \\
\left(\mathrm{m}^{2}\right)\end{array}$ & $\%$ & sd & $\begin{array}{c}\text { Measured } \\
\left(\mathrm{m}^{2}\right)\end{array}$ & sd & $\begin{array}{c}\text { MRE } \\
\left(\mathrm{m}^{2}\right)\end{array}$ & $\%$ & sd & $\begin{array}{c}\text { Measured } \\
\left(\mathrm{m}^{2}\right)\end{array}$ & $\%$ & $\begin{array}{l}\text { MRE } \\
\left(\mathrm{m}^{2}\right)\end{array}$ & $\%$ \\
\hline \multirow[t]{5}{*}{ Eurach } & 1 & Spruce & 1363 & & 1288 & 94 & & 879 & & 956 & 109 & & 484 & 36 & 331 & 26 \\
\hline & 2 & & 955 & & 1174 & 123 & & 727 & & 881 & 121 & & 228 & 24 & 293 & 25 \\
\hline & 3 & & 1095 & & 1293 & 118 & & 771 & & 866 & 112 & & 324 & 30 & 427 & 33 \\
\hline & 4 & & 1135 & & 1217 & 107 & & 754 & & 899 & 119 & & 380 & 34 & 318 & 26 \\
\hline & Average & & 1137 & 146 & 1243 & 109 & $\mathbf{5 0}$ & 783 & 58 & 901 & 115 & 34 & 354 & 31 & 342 & 28 \\
\hline \multirow[t]{6}{*}{ Starnberg } & 1 & Beech & 1219 & & 948 & 78 & & 746 & & 700 & 94 & & 473 & 39 & 247 & 26 \\
\hline & 2 & & 980 & & 941 & 96 & & 639 & & 668 & 105 & & 340 & 35 & 273 & 29 \\
\hline & 3 & & 885 & & 599 & 68 & & 514 & & 499 & 97 & & 370 & 42 & 101 & 17 \\
\hline & 4 & & 839 & & 676 & 81 & & 494 & & 602 & 122 & & 345 & 41 & 74 & 11 \\
\hline & 5 & & 639 & & 549 & 86 & & 597 & & 491 & 82 & & 43 & 7 & 58 & 11 \\
\hline & Average & & 912 & 189 & 743 & 81 & 169 & 598 & 91 & 592 & 99 & 86 & 314 & 34 & 151 & 20 \\
\hline \multirow[t]{7}{*}{ Freising } & 1 & Mixed & 2669 & & 2457 & 92 & & 1759 & & 1818 & 103 & & 910 & 34 & 639 & 26 \\
\hline & 2 & & 2747 & & 3469 & 126 & & 2266 & & 2597 & 115 & & 481 & 18 & 872 & 25 \\
\hline & 3 & & 1426 & & 1597 & 112 & & 1112 & & 1213 & 109 & & 315 & 22 & 384 & 24 \\
\hline & 4 & & 1541 & & 1646 & 107 & & 1125 & & 1189 & 106 & & 416 & 27 & 456 & 28 \\
\hline & 5 & & 1807 & & 1387 & 77 & & 992 & & 960 & 97 & & 815 & 45 & 426 & 31 \\
\hline & 6 & & 2242 & & 1789 & 80 & & 1215 & & 1310 & 108 & & 1027 & 46 & 479 & 27 \\
\hline & Average & & 2072 & 518 & 2057 & 99 & 714 & 1411 & 454 & 1515 & 107 & 549 & 661 & 32 & 543 & 26 \\
\hline
\end{tabular}

crown overlap is also subjected to errors. Again, species-specific differences have to be considered since the predicted overlap for spruce trees is quite close to the measurementbased calculations. This finding strengthen the assumption that a separate calculation of different crown layers may be necessary.

The MRE method aims not preliminary on a precise estimate of crown projection area or canopy cover. Over all, the logarithmic approach, which is used here as an example for similar and sometimes more sophisticated procedures (e.g. $[13,17,51])$, produced slightly better results and would perform even better if parameters would have been fitted for each plot separately. Furthermore, the estimates produced with the MRE method seem to be more sensitive to stand density effects than established estimation methods [9] - at least for trees with inflexible crowns.

However, the author has found no other approach that estimates crown radii for different cardinal directions. Thus, the demand for crown asymmetry-information that has been formulated in various fields of research (scaling, light modelling, estimation of windthrow susceptibility, wood quality, and crown biomass) can currently only be fulfilled with actual measurements. Despite the scatter, the immanent bias, and the dependency of accuracy on species and stand density, the MRE method may thus be used as a substitute for measured crown radii in cases where these are not available but information about crown asymmetry is needed. While stem diameter, tree height, and crown length are often directly measured or can be estimated with suitable equations (e.g. [24, 36]), the acquisition of tree position data in the field may be more difficult and expensive. However, also tree positions can be gener- ated based on stand inventory data (e.g. [39]), which may be sufficient for many of the purposes mentioned above.

Acknowledgements: This research has been conducted within the framework of the joint-research project 'Growth and Parasite Defence', funded by the German Research Agency (DFG). The Chair of Forest Yield Science, lead by Hans Pretzsch, supported the research generously with the supply of basic data, collected and processed by Martin Nickel, Leonhard Steinacker, and Martin Bachmann. Furthermore, I'd like to thank Hans Pretzsch, Greg Biging (Berkeley University, California), and the two anonymous reviewers, who made valuable comments to the manuscript, as well as Thomas Seifert, who provided yet unpublished data for the parameter estimation of crown shape for spruce trees.

\section{REFERENCES}

[1] Akça A., Aerophotogrammetrische Messung der Baumkronen, AFZ/Der Wald 30 (1983) 772-773.

[2] Alsheimer M., Köstner B., Falge E., Tenhunen J.D., Temporal and spatial variation in transpiration of Norway spruce stands within a forested catchment of the Fichtelgebirge, Germany, Ann. Sci. For. 55 (1998) 103-123.

[3] Arney J.D., Computer Simulation of Douglas-fir Tree and Stand Growth. Philosophy, Oregon State University, 1972.

[4] Assmann E., Die Theorie der Grundflächenhaltung und die Praxis der Bestandespflege bei der Rotbuche, Forst- u. Holzwirt /5 (1954).

[5] Baldwin J.V.C., Peterson K.D., Clark III A., Ferguson R.B., Strub M.R., Bower D.R., The effects of spacing and thinning on stand and tree characteristics of 38-year old Loblolly Pine, For. Ecol. Manage. 137 (2000) 91-102.

[6] Bella I.E., A new competition model for individual trees, For. Sci. 17 (1971) 364-372.

[7] Biging G.S., Dobbertin M., Evaluation of competition indices in individual tree growth models, For. Sci. 41/2 (1995) 360-377. 
[8] Biging G.S., Wensel L.C., Estimation of the crown form for six conifer species of northern California, Can. J. For. Res. 20 (1990) $1137-1142$.

[9] Bonnor G.M., The Influence of Stand Density on the Correlation of Stem Diameter with Crown Width and Height for Lodgepole Pine, For. Chron. 40/3 (1964) 347-349.

[10] Brunner A., A light model for spatially explicit forest stand models, For. Ecol. Manage. 107 (1998) 19-46.

[11] Cescatti A., Modelling the radiative transfer in discontinuous canopies of asymmetric crowns. I. Model structure and algorithms, Ecol. Modell. 101/2-3 (1997) 263-274.

[12] Chen H.Y.H., Klinka K., Kayahara G.J., Effects of light on growth, crown architecture, and specific leaf area for naturally established Pinus contorta var. latifolia and Pseudotsuga menziesii var. glauca saplings, Can. J. For. Res. 26 (1996) 1149-1157.

[13] Crookston N.L., Stage A.R., Percent canopy cover and stand structure statistics from the Forest Vegetation simulator, no. RMRS GTR-24, Department of Agriculture, Forest Service, Rocky Mountain Research Station, Ogden, UT, 1999.

[14] Deleuze C., Hervé J.C., Colin F., Modelling crown shape of Picea abies: spacing effects, Can. J. For. Res. 26 (1996) 1957-1966.

[15] Dubrasich M.E., Hann D.W., Tappeiner II J.C., Methods for evaluating crown area profiles of forest stands, Can. J. For. Res. 27 (1997) 385-392.

[16] Franz F., Pretzsch H., Nüsslein S., Strukturentwicklung und Wuchsverhalten von Buchenbeständen - Ertragskundliche Merkmale des Schirmschlag-Femelschlag-Verjüngungsverfahrens im Spessart, Allg. Forst- und Jagdztg. 160/6 (1989) 114-123.

[17] Gill S.J., Biging G.S., Murphy E.C., Modeling conifer tree crown radius and estimating canopy cover, For. Ecol. Manage. 126 (2000) 405-416.

[18] Gilmore D.W., Equations to describe crown allometry of Larix require local validation, For. Ecol. Manage. 148 (2001) 109-116.

[19] Goelz J.C.G., Open-grown crown radius of eleven bottom-land hardwood species: prediction and use in assessing stocking, S.J. Appl. For. 20/3 (1996) 156-161.

[20] Grauer A., Auswirkungen unterschiedlicher Moorwasserstände auf das Wachstum von Fichtenbeständen im Versuch EURACH 259 Lehrstuhl f. Waldwachstumskunde, TUM, Freising, 2000.

[21] Grote R., Foliage and branch biomass estimation of coniferous and deciduous tree species, Silva Fennica 36 (2002) 779-788.

[22] Grote R., Von der Baumdimension zur Biomasse und wieder zurück - Ein neuer Ansatz zur dynamischen Modellierung von Baum- und Bestandesbiomassen, in: Dietrich H.-P., Raspe S., Preuhsler T. (Eds.), Inventur von Biomasse- und Nährstoff vorräten in Waldbeständen, Wissenschaftszentrum Weihenstephan, München, 2002, pp. 129-138.

[23] Grote R., Pretzsch H., A Model for Individual Tree Development Based on Physiological Processes, Plant Biology 4/2 (2002) 167-180.

[24] Hasenauer H., Dimensional relationships of open-grown trees in Austria, For. Ecol. Manage. 96 (1997) 197-206.

[25] Honer T.G., Crown shape in open- and forest-grown balsam fir and black spruce, Can. J. For. Res. 1 (1971) 203-207.

[26] Ishii H., Clement J.P., Shaw D.C., Branch growth and crown form in old coastal Douglas-fir, For. Ecol. Manage. 131 (2000) 81-91.

[27] Iwasa Y., Cohen D., Cohen J.A.L., Tree Height and Crown Shape as Results of Competitive Games, J. Theoret. Biol. 112 (1984) 279-297.

[28] Kellomäki S., Ikonen V.-P., Peltola H., Kolström T., Modelling the structural growth of Scots pine with implications for wood quality, Ecol. Modell. 122 (1999) 117-134.

[29] Kikuzawa K., Umeki K., Effect of Canopy Structure on Degree of Asymmetry of Competition in Two Forest Stands in Northern Japan, Ann. Bot. 77 (1996) 565-571.

[30] Kramer H., Zur Qualitätsentwicklung junger Kiefernbestände in Abhängigkeit vom Ausgangsverband, Der Forst- und Holzwirt 32/ 23 (1977) 1-7.

[31] Laar van A., The Influence of Stand Density on Crown Dimensions of Pinus radiata D. Don, Forestry in South Africa 3 (1963) 133-143.
[32] Mäkelä A., Vanninen P., Impacts of size and competition on tree form and distribution of aboveground biomass in Scots pine, Can. J. For. Res. 28/2 (1998) 216-227.

[33] Mayer R., Kronengröße und Zuwachsleistung der Traubeneiche auf süddeutschen Standorten, Allg. Forst- und Jagdztg. 129 (1958) $105-114$.

[34] Medhurst J.L., Beadle C.L., Crown architecture and leaf area index development in thinned and unthinned Eucalyptus nitens plantations, Tree Physiol. 21 (2001) 989-999.

[35] Mitchell K.J., Dynamics of simulated yield of Douglas-fir, For. Sci. Monogr. 17 (1975) 1-39.

[36] Monserud R.A., Marshall D., Allometric crown relations in three northern Idaho conifer species, Can. J. For. Res. $29 / 5$ (1999) 521-535.

[37] Oltchev A., Constantin J., Gravenhorst G., Ibrom A., Heimann J., Schmidt J., Falk M., Morgenstern K., Richter I., Vygodskaya N., Application of a six-layer SVAT model for simulation of evapotranspiration and water uptake in a spruce forest, J. Phys. Chem. Earth 21/3 (1996) 195-199.

[38] Opie J.E., Predictability of individual tree growth using various definitions of competing basal area, For. Sci. 14 (1968) 314-323.

[39] Pommerening A., Biber P., Stoyan D., Pretzsch H., Neue Methoden zur Analyse und Charakterisierung von Bestandesstrukturen, Forstw. Cbl. 1/2 (2000) 62-78.

[40] Pretzsch H., Konzeption und Konstruktion von Wuchsmodellen für Rein- und Mischbestände. Forstliche Forschungsberichte München. Vol. 115, Forstwissenschaftliche Fakultät der Universität München, München, 1992.

[41] Pretzsch H., Biber P., Dursky J., The single tree-based stand simulator SILVA: construction, application and evaluation, For. Ecol. Manage. 162 (2002) 3-21.

[42] Pretzsch H., Kahn M., Grote R., Die Fichten-Buchen-Mischbestände des Sonderforschungsbereiches "Wachstum oder Parasitenabwehr?' im Kranzberger Forst, Forstw. Cbl. 117 (1998) 241-257.

[43] Röhle H., Vergleichende Untersuchungen zur Ermittlung der Genauigkeit bei der Ablotung von Kronenradien mit dem Dachlot und durch senkrechtes Anvisieren des Kronenrandes, Forstarchiv 57 (1986) 67-71.

[44] Röhle H., Huber W., Untersuchungen zur Methode der Ablotung von Kronenradien und der Berechnung von Kronengrundflächen, Forstarchiv 56 (1985) 238-243.

[45] Seifert T., Integration von Holzqualitätsmodellen in den Waldwachstumssimulator SILVA, in: Jahrestagung. Schwarzberg, Sektion Ertragskunde des Deutschen Verbandes Forstlicher Forschungsanstalten, 2002

[46] Skatter S., Kucera B., Tree breakage from torsional wind loading due to crown asymmetry, For. Ecol. Manage. 135 (2000) 97-103.

[47] Song B., Chen J., Desanker P.V., Reed D.D., Modeling canopy structure and heterogeneity across scales: From crowns to canopy, For. Ecol. Manage. 96 (1997) 217-229.

[48] Stadt K.J., Lieffers V.J., MIXLIGHT: a flexible light transmission model for mixed-species forest stands, Agric. For. Meteorol. 102 (2000) 235-252.

[49] Utschig H., Analyzing the development of regeneration under crown cover: Inventory methods and results from 10 years of observation, in: Skovsgaard J.P., Burkhart H.E. (Eds.), IUFRO - Recent Advances in Forest Mensuration and Growth and Yield Research, Danish Forest and Landscape Research Institute/Ministry of Environment and Energy, Tampere, Finland, 1995, pp. 234-241.

[50] Wang Y.P., Jarvis P.G., Description and validation of an array model - MAESTRO, Agric. For. Meteorol. 51 (1990) 257-280.

[51] Warbington R., Levitan J., How to estimate canopy cover using maximum crown width/DBH relationships, in: Stand Inventory Technologies '92 Conference, Portland, OR, Am. Soc. for Photogrammetry and Remote Sensing, Bethesda, MD, USA, 1992.

[52] Wile B.C., Crown Size and Stem Diameter in Red Spruce and Balsam Fir, no. 47-1056, Department of Forestry, Forest Research Branch, Ottawa, Canada, 1964. 